\title{
Physical therapy in the treatment of adult and paediatric spinal deformities: the Spinecor method
}

\author{
Ana del Campo \\ From 7th International Conference on Conservative Management of Spinal Deformities \\ Montreal, Canada. 20-22 May 2010
}

The main therapeutic principle utilised in SpineCor Bracing, the Corrective Movement Principle, has been shown to be effective in the treatment of Idiopathic Scoliosis over the past 15 years. More recently the Corrective Movement Principle by the utilisation of the SpineCor brace is being applied for treating abnormal spinal loading and abnormal posture in adult scoliosis patients suffering from back pain. Initial results in adult treatment demonstrated significant reduction in numerical pain scores and a moderate Cobb angle reduction.

The SpineCor Brace itself may be considered as a postural re-education tool rather than a brace, providing low impact rehabilitation exercises 10's of thousands of time per day. These corrective postural exercises have a positive effect on the abnormal loading of the spine as well as provide neuromuscular re-education with the final objective of neuromuscular integration.

The SpineCor Physical Therapy Method has been developed and utilised over the past 5 years initially to complement bracing. The therapy follows the same Corrective Movement Principle as the SpineCor brace in order to reinforce the integration of this Corrective Movement by the execution of postural re-education and muscular re-balance exercises which are scoliosis type specific.

SpineCor physiotherapy exercises have been designed with the same treatment objectives as the SpineCor brace being the correction/stabilisation of the spinal

The SpineCorporation Ltd, Alicante, Spain

Full list of author information is available at the end of the article deformities/misalignments when possible, postural improvement and pain relief.

Published: 10 September 2010

doi:10.1186/1748-7161-5-S1-031

Cite this article as: del Campo: Physical therapy in the treatment of adult and paediatric spinal deformities: the Spinecor method. Scoliosis 2010 5(Suppl 1):031.
Submit your next manuscript to BioMed Central and take full advantage of:

- Convenient online submission

- Thorough peer review

- No space constraints or color figure charges

- Immediate publication on acceptance

- Inclusion in PubMed, CAS, Scopus and Google Scholar

- Research which is freely available for redistribution

Submit your manuscript at www.biomedcentral.com/submit
C Biomed Central 